\title{
Accounting-based Digital Payment Systems for SMEs
}

\author{
Ridwan Sanjaya \\ Information Systems Department \\ Soegijapranata Catholic University \\ Semarang, Indonesia \\ ridwan@unika.ac.id
}

\author{
Theresia Dwi Hastuti \\ Accounting Department \\ Soegijapranata Catholic University \\ Semarang, Indonesia \\ theresia@unika.ac.id
}

\author{
G. Freddy Koeswoyo \\ Accounting Department \\ Soegijapranata Catholic University \\ Semarang, Indonesia \\ freddy@unika.ac.id
}

\begin{abstract}
Batik SMEs who have successfully sold their products through e-marketplace are now entering a new stage. They need the management of financial data from sales to bankable accounting reports. All existing e-marketplaces in Indonesia are only providing visitor statistics and sales reports without providing any features for accounting reports. The problem is the ability of the SMEs to make financial statements only uses simple calculations based on income, expenses, and notes on debt and accounts receivable. This habit has been carried out for years, causing difficulties in obtaining the detailed financial information needed by financial institutions and for business development purposes. The integration of accounting software into e-marketplaces should be added to facilitate SMEs who lack the ability to make financial reports. This feature is expected to automate financial statements until the report can be approved by financial institutions. This paper reviews the availability and possibility of the digital payment system in e-marketplaces to provide embedded accounting features, open access to integration of accounting software from third parties and propose suitable model for SMEs.
\end{abstract}

Keywords - accounting reports, bankable reports, digital payment system, financial statements, report automation

\section{INTRODUCTION}

Internet users in Indonesia have increased in the last 10 years. Based on the Internet World Stats data [1], the number of internet users in Indonesia was only around 20 million in 2007, but the number of internet users increased 660 percent to 132.7 million users in 2017 . The number of internet users has even grown to 143 million users by the end of 2018. Based on a survey conducted by APJII or the Indonesia Internet Service Provider Association in 2017 [2], internet users are dominated by millennials. Around 49.52 percent of users are aged 19 to 34 years, 29.55 percent of users are aged 35 to 54 years, 16.68 percent are aged 13 to 18 years, and only 4.24 percent are over 54 years. The increasing number of internet users and proportion of young internet users has an impact on lifestyle changes in Indonesian society, especially in the purchase of goods. They prefer to buy products at the online shop.

The development of civil infrastructure in Indonesia also affected many people. For example, the development of the new expressways cause changes in the travel routes of travellers [3]. Previously, they might have stopped in several cities in the route to take a rest but now they can go straight to the end point. The new habit of travellers creates an economic impact for people who rely on travellers who use normal roads. The travellers who usually make purchases on their visits also experience a decline. Batik sellers in Lasem (Indonesia) also feel the same situation. The sellers usually rely on travellers who have travel routes between the provincial capitals. The expressway has diverted many travellers from their city because it shortens travel time between the provincial capitals.

Therefore, the addition of online sales channels is an inevitable choice. The use of e-marketplaces is one of the easiest ways to get involved in the online sales globally. The reasons are the sellers do not need to pay any initial costs or make an investment to have a shop in the e-marketplace, various payment mechanisms are available, and provided shipping services are connected to the integrated tracking feature. Other benefits that can attract buyers are discounted shipping costs for certain purchase values and discounted selling prices for credit card users which are quite often available but not the seller's expense.

Based on data from iPrice in 2019, Tokopedia, Shopee, BukaLapak are the top three e-marketplace brands in Indonesia since last year. Those three e-marketplaces help many sellers related to marketing and sales in the digital world. However, small and medium scale sellers still have the same problem as previous when they were still conducting conventional transactions, such as making financial reports that can be used for business development and bankable. The problem is caused by the inability of the SMEs in making of financial statements. They only use simple calculations based on income, expenses, and notes on debt and accounts receivable. They need the management of financial data from sales to bankable accounting reports. However, all existing emarketplaces in Indonesia are only providing visitor statistics and sales reports without providing any features for accounting reports. The integration of accounting software into e-marketplaces should be added to facilitate SMEs who lack the ability to make financial reports. This feature is expected to automate financial statements until the report can be approved by financial institutions.

Besides the mainstream payment method in emarketplaces, there is another popular payment method which can be used to receive payments from several e-wallets and ebanking application via QR code [5]. QR code is a form of 2D barcode which one of its functions is used for payment [6]. This payment method can also help SME's to ease in receiving payments via website from the buyer using various banks or e-wallets. This payment method in Indonesia is called as QRIS (QR code Indonesian Standard). There are two kinds of QRIS which is static QRIS and dynamic QRIS. A static QRIS is a QR code image for receiving any payments from buyers to a specific seller, but the buyers should input the amount of 
money by themselves. The sellers do not need to provide any IT infrastructure to have static QRIS in their online and/or offline shop. In the other hand, a dynamic QRIS is a QR code image for receiving a payment from a specific buyer to a specific seller and it has a usage time validity limit [7]. Its QR code is generated based on the purpose and specific amount of money. The dynamic QRIS payment system needs an IT infrastructure and information system to record the transaction and link its information to the QR code. The accounting program can be added or linked to the information system. This feature will create financial statements automatically to ease the SME's in providing the bankable accounting reports.

\section{CONCEPTS OVERVIEW}

According to Wang and Archer [8], electronic marketplaces or e-marketplaces are places where buyers and sellers conduct transactions by electronic means. Emarketplaces can be defined as interactive business groups providing a market space where multiple merchants can engage in e-commerce and other e-business activities [9]. Emarketplace governance is determined by the e-marketplace owner, including the provision of features to support sellers [10].

Even though e-marketplaces are the place for marketing and sales activities, e-marketplaces also have functions similar to the Point of Sales (POS) software, which record all sales activities. Currently, there are a lot of additional software to be integrated with POS software for accounting purposes. Sleekr Accounting and Accurate Accounting are the examples. Sleekr Accounting could be added in the MOKA Point of Sales (MOKAPOS) software as an additional feature for accounting purposes [11]. Accurate Accounting could be integrated also in the MOKAPOS and RENE 2 Point of Sales [12]. Data generated from accounting software can be imported into the main accounting program to be further processed into a comprehensive accounting report. The sellers do not have to have an accounting major or take an accounting course. The accounting reports can be processed automatically after data integration. This concept can be adapted into the emarketplace platform to facilitate accounting activities in sales transactions.

The integration of a cloud-based accounting in Point of Sales (POS) software can be applied to e-marketplaces platforms. All activities that have financial value are automatically journalized when the order transaction starts, accepts payment, until the transaction is successfully completed. The Application Program Interface (API) shall bridging e-marketplaces to produce data, transfer data, and combine data into major accounting software. Bankable accounting reports can be easily generated by sellers through the data processing automation mechanism.

Another new approach to meet the need to produce bankable accounting reports can be facilitated through the payment methods using QR code or it is called as QR Payment method. The standardized QR payment named QRIS (Indonesian QR code Standard) in Indonesia was proposed by the government to make the inclusive financial and facilitate the financial institutions in receiving payments from all major electronic wallets (e-wallets) and electronic banking (ebanking) applications. The sellers do not need to subscribe to various e-wallets to be able to receive all payments from customers who have different e-wallets.
The advantage, all payments using QRIS can be recorded by using the information system which is connected to the database. If the QRIS is dynamic or dynamically created based on the system, all transactions can be individually identified and recorded for accounting records or linked to the existing accounting programs. The Application Program Interface (API) is also needed to integrating the data from the server into the existing accounting programs.

This second approach requires the hardware investment or cloud server which has information systems to record sales transactions and data conversion into accounting reports. Buyers only need to subscribe one e-wallet or use one ebanking application. The costs incurred by the seller in providing QRIS payment facilities are not more than 0.7 percent of the transaction value. This approach will help many sellers in automatically recording the transactions in the form of bankable accounting reports and at the same time connect the sellers to a bank that is ready to help them.

\section{STRATEGIES}

In fact, the big three e-marketplaces in Indonesia do not provide an Application Program Interface (API) for connecting third party software such as MOKA and RENE 2 Point of Sales. It needs more time to develop the API for any accounting software. However, the scope of needs should be minimized to make the accounting easier. Recorded transactions must be limited only for selling transactions because most of e-marketplace platforms do not record buying transaction. Moreover, the transactions could be recorded using minimum information that meet accounting standard, such as date of transaction, ID of transaction, description of transaction, account number $(\mathrm{CoA})$, value of transaction, and debit or credit status.

For the example, figure 1 shows the journal entries for sales will record Cash in debit, Revenues (Sales) in credit, Cost of goods sold in debit, and Inventory in credit.

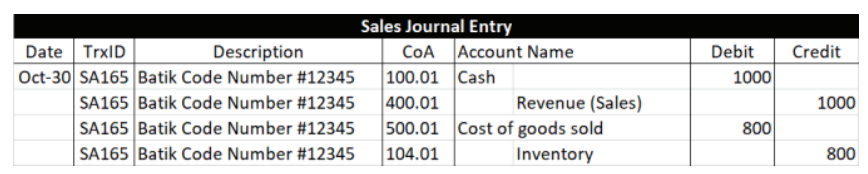

Fig. 1. The example of sales journal entry

The journal entries for this transaction will be converted into database format in order to meet the data exchange purposes. Figure 2 is the example of the database records for data exchange between e-marketplace and main accounting software.

\begin{tabular}{|c|c|c|c|c|}
\hline Date & TrxID & CoA & \multicolumn{2}{|c|}{ Value } \\
\hline $2019-10-30$ & SA165 & 100.01 & 1000 & D \\
\hline $2019-10-30$ & SA165 & 400.01 & 1000 & C \\
\hline $2019-10-30$ & SA165 & 500.01 & 800 & D \\
\hline $2019-10-30$ & SA165 & 104.01 & 800 & C \\
\hline
\end{tabular}

Fig. 2. Database records for data exchange

The records will be used as a base for export and import between e-marketplace platform and the accounting software. 


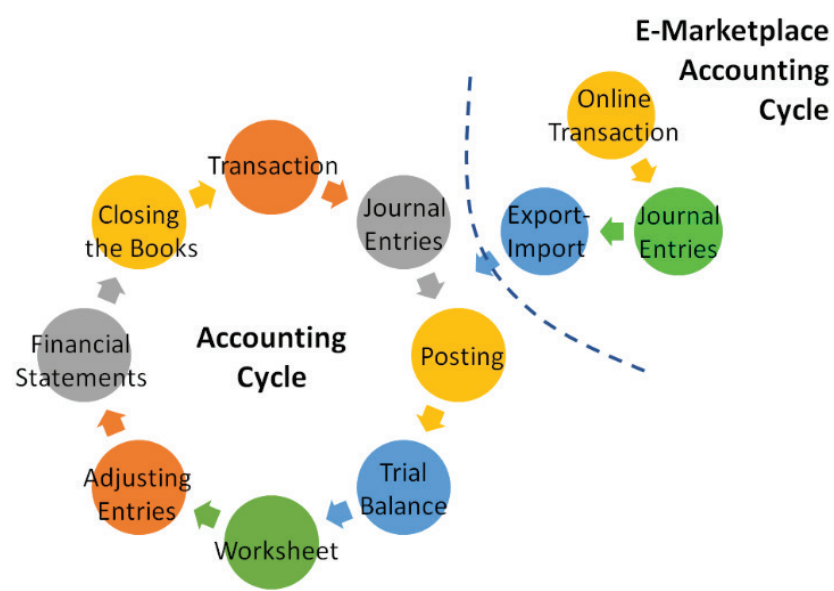

Fig. 3. Accounting Integration for e-marketplace transactions

The second approach that uses a dynamic QR code payment basically requires a system that creates a specific QR Code based on the payment code that has been marked for the purposes of identifying each transaction and connecting to the database [13]. The approach that uses QRIS payment basically requires a system that creates a specific QR Code based on the payment code that has been marked for the purposes of identifying each transaction and connecting to the database. The resulting journal entries can be the same as the previous approach.

First of all, the seller must ask the bank for QRIS payment method support in order to obtain an API to receive payments through that method. Each API has an authorization access to receive payments to each seller's account. Each sales transaction will produce a different QR code. When a buyer makes a payment using this method, the program will be triggered to check the transaction status in the banking system. When the payment status is declared successful, then the recording of transaction data and converting them into data for accounting report can be started.

Similar with the first approach, the transactions could be recorded using minimum information, but it should meet the accounting standard. The database can also record date of transaction, ID of transaction, description of transaction, account number (CoA), value of transaction, and debit or credit status. The value of transaction will be filled from the amount of QR code payment generated from the system.

In the next step, journal entries of the transaction will be converted into database format also for the data exchange purposes. The records will be used as a base for export and import between the digital payment system and the accounting software. Then, the records will be used to generate the other accounting reports that is needed by the financial institution.

\section{IMPLEMENTATION}

Providing the feature to export simple accounting for selling transaction in the e-marketplace platform is the easier approach for implementation. The exporting result could be in XML or CSV format, the most common file format for data exchange [14], [15]. Then, the files could be imported to the main accounting software, both desktop and cloud based. It will be imported as an additional journal entry in the main accounting software. Moreover, the journal entries will be processed for posting step and the rest of accounting cycle.

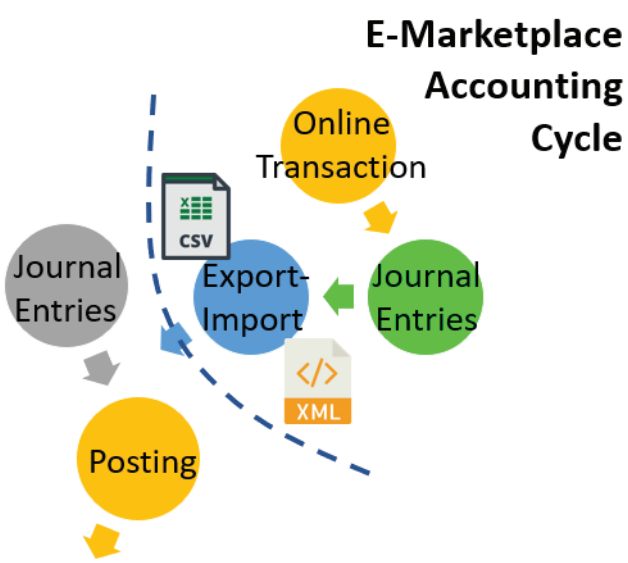

Fig. 4. XML or CSV format for data exchange

However, the practice may not easy to ask e-marketplace owner for adding these features, even though the features will be included in premium services. If those features are possible to be created, then the main accounting software are able to import the data from the e-marketplace. If those features are not possible to be realized, then the accounting software developers should provide add-ons in a web browser to read the e-marketplace transaction reports on the web page and convert them into journal entries. Then, journal entries will be generated as an XML or CSV file to be imported into the main accounting software.

Providing the digital payment systems using QR code may need an independent e-commerce website. It has the flexibility to create its own accounting reporting feature triggered by the digital payment system. Banks or e-wallet providers have the opportunity to offer this benefit to their merchant. If it is connected to the e-marketplace payment system, it can interact the sellers to subscribe as their merchants and improve the positive image of e-marketplace.

\section{CONCLUSIONS}

There are many cloud-based accounting's systems which are possible to be integrated with e-marketplace platforms by providing an Application Program Interface (API). A similar situation can be seen in Point of Sales (POS) software which is also cloud based and makes simple sales records. Simple accounting reports can be generated from sales transactions in e-marketplaces and are possible to be imported into the main accounting application. Data transfer from e-marketplaces to cloud-based accounting systems should not be created manually. It can be automated by both applications without any user intervention.

Sales data from the digital payment system must be translated into journal entries and imported by main accounting software. Both developer of e-marketplace platform and accounting software are possible to provide the accounting feature using a minimum effort. There are two ways to read data in an e-marketplace, which are through the e-marketplace owner and using the web browser's add-on.

The digital payment system that use QR code also has a possibility to help the merchants in obtaining accounting reports automatically. Each payment can be stored in the database and converted as journal entry. It also possible to be integrated into an accounting application or a cloud-based 
accounting system. The journal entry will be a basis for connecting the accounting applications.

The results of reading data from the electronic transaction platform will be translated into XML or CSV file. The file will be imported by main accounting software. Merging data from the e-marketplace and main accounting software could be done easily through the import feature. As the result, the complete and bankable financial reports can be produced.

\section{ACKNOWLEDGMENT}

This research was funded by the Indonesian Ministry of Research and Higher Education under the scheme of Higher Education Applied Research Excellence Grant on 2019 which titled as SMEs Information System Innovation to Support the Independence of Business Decision Making and Creative Economy Development.

\section{REFERENCES}

[1] Miniwatts Marketing Group., "Internet Usage in Asia," 2017. [Online]. Available: https://www.internetworldstats.com/stats3.htm.

[2] Association Indonesia Internet Service Provider, "Penetrasi \& perilaku pengguna internet indonesia (Penetration \& behavior of Indonesian internet users)," 2017.

[3] I. G. Ayu Andani, K. Geurs, and L. L. P. Puello, "Effects of toll road construction on local road projects in Indonesia," J. Transp. Land Use, vol. 12, no. 1, pp. 179-199, 2019.

[4] iPrice, "The Biggest E-commerce Website and Apps in Southeast Asia Q1 2019," 2019.

[5] Y. U. Chandra, D. M. Kristin, J. Suhartono, F. S. Sutarto, and M. Sung, "Analysis of Determinant Factors of User Acceptance of Mobile Payment System in Indonesia (A Case Study of Go-Pay Mobile Payment)," in Proceedings 2018 International Conference on Information Management and Technology (ICIMTech), 2018, pp. 454459.

[6] S. Shetty and T. Shetty, "QR-Code based Digital Wallet," Int. J. Adv. Res. Comput. Sci., vol. 5, no. 7, pp. 105-109, 2014.

[7] H. Baidong and Z. Yukun, "Research on Quickpass Payment Terminal Application System Based on dynamic QR Code," J. Phys. Conf. Ser., vol. 1168 , no. 3, 2019.

[8] S. Wang and N. P. Archer, "Electronic marketplace definition and classification: literature review and clarifications," Enterp. Inf. Syst., vol. 1, no. 1, pp. 89-112, 2007.

[9] P. Brunn, M. Jensen, B. C. Group, and J. Skovgaard, "e-Marketplaces : Crafting A Winning Strategy,” Eur. Manag. J., vol. 20, no. 3, pp. 286298, 2002.

[10] D. Truong, T. T. Le, S. Senecal, and S. S. Rao, "Journal of Businessto-Business Electronic Marketplace : A Distinct Platform for Businessto-Business ( B-to- B ) Procurement Electronic Marketplace: A Distinct Platform," J. Business-to-bus. Mark., no. August, pp. 37-41, 2012.

[11] Sleekr, "Sleekr Accounting is available at the MOKA POS Marketplace (Sleekr Accounting hadir di MOKA POS Marketplace)," 2018. [Online]. Available: https://sleekr.co/blog/sleekr-accountingmoka-pos-marketplace/.

[12] Accurate, "RENE 2 Integrated POS with Accounting Software (RENE 2 POS yang Dapat Terintegrasi dengan Software Akuntansi)," 2017. [Online]. Available: https://accurateofficial.com/rene-2/.

[13] R. Alhafi et al., "E-Payment and Transactions using QR Codes," Int. Res. J. Eng. Technol., vol. 6, no. 2, pp. 433-443, 2019.

[14] Y. Yang, "Impact Data-Exchange based on XML," Proc. 2012 7th Int. Conf. Comput. Sci. Educ., no. Iccse, pp. 1147-1149, 2012.

[15] G. Goyal, K. Singh, and K. R. Ramkumar, "A detailed analysis of data consistency concepts in data exchange formats (JSON \& XML)," Proc. 2017 IEEE Int. Conf. Comput. Commun. Autom., pp. 72-77, 2017. 